\title{
Analisis K-Medoids Clustering Dalam Pengelompokkan Data Imunisasi Campak Balita di Indonesia
}

\author{
Siti Sundari', Irfan Sudahri Damanik ${ }^{2}$, Agus Perdana Windarto ${ }^{3}$, Heru Satria Tambunan, \\ Jalaluddin $^{5}$, Anjar Wanto 6 \\ ${ }^{1}$ Mahasiswi Sistem Informasi STIKOM Tunas Bangsa Pematangsiantar, Indonesia \\ 2,3,4,5,6Dosen STIKOM Tunas Bangsa Pematangsiantar, Indonesia \\ Jl. Jend Sudirman Blok A No 1,2,3 Pematangsiantar, Indonesia \\ sitisundari751@gmail.com
}

\begin{abstract}
Measles is a contagious infections disease that attacks children caused by a virus. Transmission of measles from people through coughing and sneezing. Measles causes disability and death, so further threatment is needed. Measles immunization program that can inhibit the development of measles is one of the efforts in eradicating the disease. In this study the data used were sourced from the Central Statistics Agency National in 2013-2017. This study uses datamining techniques in data processing with K-Medoids algorithm. The KMedoids method is a clustering method that functions to break datasets into groups. The advantages of this method are the ability to overcome the weaknesses of the K-Means method which is sensitive to outliers. Another advantage of this algorithm is that the results of the clustering process do not depend on the entry sequence of the dataset. The k-medoids clustering method can be applied to the data on the percentage of measles immunization can be identified based on province, so that the grouping of provinces based on these data. From the data grouping three clusters are obtained: low cluster (2 provinces), medium cluster (30 provinces) and high cluster (2 provinces) with the percentage of measles immunization in each of these provinces from data grouping in percentage. It is expected this research can provide information to the govermant about the data on grouping measles immunization for toddlers in Indonesia which has an impact on the distribution of immunization against measles toddlers in Indonesia.
\end{abstract}

Keywords: Data Mining, K-Medoids Clustering, Measles Immunization

Abstrak - Penyakit campak merupakan penyakit infeksi menular yang menyerang anakanak karena disebabkan oleh virus. Penularan penyakit campak dari orang melalui batuk dan bersin. Penyakit campak perlu ditangani karena menyebabkan kecacatan dan kematian. Program imunisasi campak merupakan salah satu upaya dalam pemberantasan penyakit campak yaitu dengan cara memberikan kekebalan tubuh yang dapat menghambat perkembangan penyakit campak tersebut. Pada penelitian ini data yang digunakan bersumber dari Badan Pusat Statistik Nasional tahun 2004-2017. Penelitian ini menggunakan teknik data mining dalam proses pengolahan data dengan metode $k$-medoids clustering. Metode k-medoids merupakan metode clustering yang berfungsi untuk memecah dataset menjadi beberapa kelompok. Kelebihan dari metode ini mampu mengatasi kelemahan dari metode $k$-means yang sensitive terhadap outlier. Kelebihan lain dari metode ini yaitu hasil proses clustering tidak bergantung pada urutan masuk dataset. Metode $k$ medoids clustering dapat diterapkan pada data persentase imunisasi campak balita berdasarkan provinsi, sehingga dapat diketahui pengelompokkan provinsi berdasarkan data tersebut. Dari data pengelompokan tersebut diperoleh 3 cluster yakni cluster rendah (2 provinsi), cluster sedang (30 provinsi) dan cluster tinggi (2 provinsi) dari persentase imunisasi campak balita pada setiap provinsi. Diharapkan penelitian ini dapat memberikan 
informasi kepada pemerintah tentang pengelompokan data imunisasi campak balita di Indonesia yang berdampak pada pemerataan dalam pemberian imunisasi campak balita di Indonesia.

Kata kunci: Data Mining, K-Medoids Clustering, Imunisasi Campak

\section{PENDAHULUAN}

Penyakit campak merupakan penyakit infeksi menular yang menyerang anak-anak maupun dewasa yang disebabkan oleh virus. Penularan penyakit campak dapat melalui kontak langsung melalui batuk dan bersin. Berdasarkan data Organisasi Kesehatan Dunia[1], Indonesia termasuk 10 negara dengan kasus campak terbesar didunia. Kementerian kesehatan mencatat jumlah kasus campak sangat banyak dan cenderung meningkat dalam kurun waktu lima tahun terakhir. Beberapa komplikasi yang dialami penderita campak diantaranya radang paru, infeksi telinga, diare dan radang otak. Penyakit campak merupakan penyebab utama kematian anak di antara penyakit yang dapat dicegah dengan imunisasi.

Berdasarkan data Kemenkes RI (2016) [2] "Indonesia memiliki cakupan imunisasi campak sebesar $84 \%$ dan termasuk kedalam kategori imunisasi campak sedang dibandingkan dengan negara lain di Asia Tenggara". Indonesia ikut serta dalam program eliminasi campak pada tahun 2020 dengan cakupan campak minimal 95\% di setiap wilayah secara merata sehingga imunisasi campak mendapatkan perhatian lebih dari pemerintah. Program imunisasi campak merupakan salah satu upaya dalam pemberantasan penyakit campak yaitu dengan memasukkan racun penyakit tertentu yang sudah dilemahkan ke dalam tubuh dengan cara disuntik atau diminum. Hal ini bertujuan untuk meningkatkan kekebalan tubuh terhadap penyakit tersebut. Di Indonesia tingkat penyakit campak pada balita masih sangat tinggi. Diperkirakan sekitar 30.000 anak Indonesia meninggal setiap tahunnya disebabkan komplikasi campak. Hal ini di buktikan dengan lebih dari 95\% kematian akibat penyakit campak yang terjadi di negara-negara didunia seperti Amerika Serikat, Inggris, Yaman, Amerika Latin, Myanmar, Afrika, Chad, Afrika Tengah, Liberia, Guinea dan Indonesia. Dalam hal ini pemerintah harus berperan aktif dan berkomitmen untuk melenyapkan penyakit campak. Oleh karena itu, untuk dapat memutuskan mata rantai penularan penyakit campak khususnya balita diperlukan imunisasi minimal 95\%. Untuk bisa mewujudkan hal ini pemerintah memerlukan data yang akurat untuk melakukan pengelompokkan data imunisasi campak balita. Data diperoleh dari BPS mengenai data persentasi imunisasi campak balita berdasarkan provinsi di Indonesia pada tahun 2004-2017.

Berdasarkan uraian diatas banyak cabang kecerdasan buatan dalam ilmu komputer yang dapat menyelesaikan permasalahan tersebut secara kompleks diantaranya sistem pendukung keputusan, sistem pakar, data mining dan lain sebagainya. Beberapa penelitian tentang data mining seperti: [3] diperoleh penilaian berdasarkan indeks Desa/Kelurahan yang memiliki sarana kesehatan dengan 4 provinsi dengan tingkat sarana kesehatan tinggi yaitu Sumatera Utara, Jawa Barat, Jawa Tengah, Jawa Timur, 14 provinsi dengan tingkat sarana kesehatan sedang, dan 16 provinsi lainnya termasuk tingkat sarana kesehatan rendah. 
Penelitian selanjutnya [4] menunjukkan bahwa dengan penggunaan 2 cluster menghasilkan kelompok data dengan potensi yang dimiliki yaitu cluster 1 termasuk dalam potensi tinggi dengan hasil rata-rata brightness sebesar $344.470 \mathrm{~K}$ dengan rata-rata confidence $87.08 \%$ dan cluster 2 masuk dalam potensi sedang dengan hasil rata-rata brightness sebesar $318.800 \mathrm{~K}$ dengan rata-rata confidence sebesar 58,73\%. Penelitian lainnya oleh [5] dihasilkan dataset dengan kodifikasi keseluruhan data menempati predikat terbaik dalam keseragaman dalam pengelompokan dengan nilai 2,245, dataset kodifikasi keseluruhan menunjukkan nilai CCC berada diantara 2 sampai 3 ini menunjukkan bahwa dataset kodifikasi keseluruhan mempunyai keseragaman yang baik. Dari beberapa penelitian tersebut data mining merupakan serangkaian proses untuk menggali nilai tambah berupa informasi yang diperoleh dengan cara mengenali pola yang penting dari data yang terdapat pada basis data. Metode $k$-medoids merupakan salah satu metode pengelompokkan dalam data mining yang merupakan bagian dari partitional clustering. Metode ini menggunakan objek pada kumpulan objek untuk mewakili sebuah cluster. "Kelebihan dari metode ini mampu mengatasi kelemahan dari metode $k$-means yang sensitive terhadap outlier dan hasil proses clustering tidak bergantung pada urutan masuk dataset" [6].

Metode $k$-medoids clustering dapat diterapkan pada data persentase imunisasi campak balita berdasarkan provinsi, sehingga dapat diketahui pengelompokkan provinsi berdasarkan data tersebut. Dari data pengelompokan tersebut dapat dilihat karakteristiknya sehingga diketahui cluster rendah, cluster sedang dan cluster tinggi dengan persentase imunisasi campak pada setiap provinsi tersebut. Berdasarkan latar belakang masalah di atas, penulis mengambil judul skripsi "Analisis K-Medoids Clustering Dalam Pengelompokkan Data Imunisasi Campak Balita di Indonesia". Diharapkan penelitian ini dapat memberikan informasi kepada pemerintah tentang data pengelompokan imunisasi campak balita di Indonesia yang berdampak pada pemerataan pemberian imunisasi campak balita di Indonesia.

\section{METODOLOGI PENELITIAN}

Penelitian ini dilakukan untuk mengaplikasikan data mining dalam pengelompokkan data imunisasi campak balita untuk menemukan tingkat imunisasi rendah supaya dapat dilakukan sosialisasi ke provinsi tersebut.

\subsection{Analisa Permasalahan}

Berdasarkan analisa yang dilakukan penulis menyimpulkan dasar permasalahan dalam penelitian ini ialah cakupan penyakit campak balita yang semakin meningkat setiap tahunnya. Indonesia termasuk 10 besar negara dengan cakupan penyakit campak terbesar didunia. Untuk dapat memutuskan mata rantai penularan penyakit campak khususnya balita diperlukan imunisasi minimal $95 \%$. Mengingat di Indonesia memiliki cakupan imunisasi campak sebesar 84\% dan termasuk kedalam kategori imunisasi campak sedang dibandingkan dengan negara lain di Asia Tenggara. Untuk itu diperlukan peningkatan lebih lanjut yaitu dengan dilakukan pemerataan ke provinsi di Indonesia. 


\subsection{Metode Pengumpulan Data}

Dalam hal pengumpulan data penulis memanfaatkan perpustakaan, buku, prosiding atau jurnal sebagai media untuk bahan referensi dalam menentukan parameter yang digunakan dalam penelitian. Sumber data penelitian diperoleh dari Badan Pusat Statistik Nasional dengan situs https://www.bps.go.id. Data yang digunakan dalam penelitian ini adalah data persentase imunisasi campak balita pada setiap provinsi dari tahun 2004-2017 yang terdiri dari 34 provinsi. Variabel yang digunakan ialah persentase imunisasi campak balita yang sudah diakumulasikan.

\subsection{Analisis Data}

Proses analisis data dapat dilakukan setelah adanya pengumpulan data. Dalam melakukan penelitian ini, penulis melakukan analisis data statistik deskriptif. Jenis data yang digunakan dalam penelitian ini adalah data sekunder. Data sekunder adalah data yang diperoleh tidak dari sumbernya langsung, melainkan sudah dikumpulkan oleh pihak lain dan sudah diolah serta memiliki keterkaitan dengan permasalahan yang diteliti.

\subsection{Algoritma K-Medoids Clustering}

Adapun metode yang digunakan dalam penelitian ini adalah metode $k$ medoids clustering. Menurut [7] "Metode $k$-medoids adalah metode pengelompokkan yang berkaitan dengan metode $k$-means dan metode medoidshift". Penelitian ini dilakukan untuk mengetahui diketahui cluster rendah, cluster sedang dan cluter tinggi dari data imunisasi campak balita pada provinsi di Indonesia.

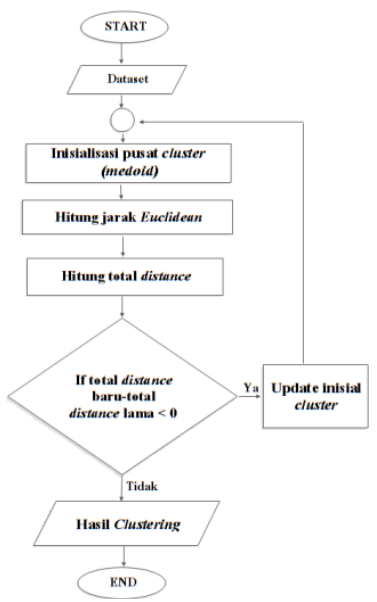

Gambar 1. Flowchart Metode K-Medoids Clustering

Berdasarkan gambar 2.1 dapat dijelaskan bahwa langkah-langkah metode $k$ medoids clustering diantaranya:

1. Inisialisasi pusat cluster sebanyak $k$ (jumlah cluster)

2. Alokasikan setiap data (objek) ke cluster terdekat menggunakan persamaan ukuran jarak Euclidian Distance dengan persamaan:

$$
d_{i j}=\sqrt{\left.\sum_{a=1}^{p}\left(x_{i a}-x_{j a}\right)^{2}=\sqrt{\left(\mathrm{x}_{i}\right.}-\mathrm{x}_{j}\right)^{\prime}\left(\mathrm{x}_{i}-\mathrm{x}_{j}\right) \ldots \ldots \ldots \ldots \ldots \ldots \ldots \ldots \ldots \ldots \ldots \ldots \ldots \ldots \ldots \ldots \ldots \ldots}
$$


dimana $i=1, \ldots . ., n ; j=1, \ldots . ., n$ dan $p$ adalah banyak variable, serta $V$ adalah matrik varian kovarian.

3. Pilih secara acak objek pada masing-masing cluster sebagai kandidat medoid baru.

4. Hitung jarak setiap objek yang berada pada masing-masing cluster dengan kandidat medoid baru.

5. Hitung total simpangan (S) dengan menghitung nilai total distance baru - total distance lama. Jika $\mathrm{S}<0$, maka tukar objek dengan data cluster untuk membentuk sekumpulan $k$ objek baru sebagai medoid.

6. Ulangi langkah 3 sampai 5 hingga tidak terjadi perubahan medoid, sehingga didapatkan cluster beserta anggota cluster masing-masing.

\section{HASIL DAN PEMBAHASAN}

\subsection{Penerapan Algoritma K-Medoids Clustering}

Pada tahapan ini pengolahan data imunisasi campak balita menurut provinsi di Indonesia menggunakan algoritma $k$-medoids. Berikut adalah data imunisasi campak balita menurut provinsi di Indonesia yang diambil penulis melalui situs Badan Pusat Statistik Nasional. Langkah-langkah dalam menyelesaikan perhitungan manual data mining menggunakan $k$-medoids clustering adalah sebagai berikut:

a. Inisialisasi pusat cluster sebanyak 3 cluster dari data sampel.

Untuk pemilihan setiap medoid dipilih secara acak (random). Diasumsikan aceh, bali dan papua sebagai medoid awal.

Tabel 1. Medoid Awal

\begin{tabular}{|c|c|c|c|c|c|c|c|}
\hline Inisial & $\mathbf{2 0 0 4}$ & $\mathbf{2 0 0 5}$ & $\mathbf{2 0 0 6}$ & $\mathbf{2 0 0 7}$ & $\mathbf{2 0 0 8}$ & $\mathbf{2 0 0 9}$ & $\mathbf{2 0 1 0}$ \\
\hline Aceh(C1) & 74,02 & 0 & 70,93 & 66,98 & 71,86 & 74,08 & 74,24 \\
\hline Bali(C2) & 83,77 & 80,38 & 85,08 & 80,26 & 83,05 & 82,96 & 82,5 \\
\hline Papua(C3) & 71,07 & 65,53 & 73,09 & 67,88 & 58,63 & 62,63 & 59,22 \\
\hline
\end{tabular}

Tabel 2. Lanjutan Medoid Awal

\begin{tabular}{|c|c|c|c|c|c|c|c|}
\hline Inisial & $\mathbf{2 0 1 1}$ & $\mathbf{2 0 1 2}$ & $\mathbf{2 0 1 3}$ & $\mathbf{2 0 1 4}$ & $\mathbf{2 0 1 5}$ & $\mathbf{2 0 1 6}$ & $\mathbf{2 0 1 7}$ \\
\hline Aceh(C1) & 74,13 & 75,1 & 74,09 & 74,11 & 60,73 & 59,09 & 53,22 \\
\hline Bali(C2) & 82,71 & 80,22 & 83,24 & 84,56 & 81,27 & 80,8 & 82,03 \\
\hline Papua(C3) & 58,68 & 62,91 & 64,54 & 63,53 & 57,61 & 55,85 & 58,77 \\
\hline
\end{tabular}

b. Menghitung nilai jarak terdekat (cost) dengan persamaan Euclidian Distance.

Untuk menghitung jarak antara titik centroid dengan titik tiap objek menggunakan Euclidian Distance. Rumus untuk menghitung jarak menggunakan persamaan (2.1). Maka perhitungan untuk menghitung jarak setiap objek dengan medoid awal adalah sebagai berikut :

$$
D_{\text {aceh }, c 1}=\sqrt{\begin{array}{c}
\left((74,02-74,02)^{2}+(0-0)^{2}+(70,93-70.93)^{2}\right. \\
+(66,98-66,98)^{2}+(71,86-71,86)^{2}+(74,08-74,08)^{2} \\
+(74,24-74,24)^{2}+(74,13-74,13)^{2}+(75,1-75,1)^{2} \\
+(74,09-74,09)^{2}+(74,11-74,11)^{2}+(60,73-60,73)^{2} \\
\left.+(59,09-59,09)^{2}+(53,22-53,22)^{2}\right)
\end{array}}=0
$$


Hasil dari keseluruhan dapat diihat pada tabel 4.3 sebagai berikut :

Tabel 3. Hasil Perhitungan Algoritma K-Medoids Iterasi ke-1

\begin{tabular}{|c|c|c|c|c|c|}
\hline \multirow[b]{2}{*}{ Provinsi } & \multicolumn{3}{|c|}{ Jarak Ke Medoid } & \multirow[b]{2}{*}{ Terdekat } & \multirow{2}{*}{$\begin{array}{c}\text { Cluster } \\
\text { Yang } \\
\text { Diikuti }\end{array}$} \\
\hline & C1 & $\mathrm{C} 2$ & C3 & & \\
\hline Aceh & 0 & 96,02538 & 74,0376 & 0 & 1 \\
\hline Sumatera Utara & 63,11258 & 57,15747 & 33,0071 & 33,0071 & 3 \\
\hline Sumatera Barat & 71,98269 & 47,38079 & 31,26423 & 31,26423 & 3 \\
\hline Riau & 70,33624 & 38,63995 & 40,05805 & 38,63995 & 2 \\
\hline Jambi & 75,34014 & 32,65599 & 44,78451 & 32,65599 & 2 \\
\hline Sumatera Selatan & 80,66526 & 21,72912 & 55,28308 & 21,72912 & 2 \\
\hline Bengkulu & 83,37242 & 17,39546 & 60,30339 & 17,39546 & 2 \\
\hline Lampung & 84,51967 & 14,76612 & 62,18156 & 14,76612 & 1 \\
\hline Kep.Bangka Belitung & 78,71582 & 26,65942 & 53,18272 & 26,65942 & 2 \\
\hline Kep. Riau & 113,5591 & 85,2557 & 95,05084 & 85,2557 & 2 \\
\hline Dki Jakarta & 87,36542 & 16,83969 & 61,94578 & 16,83969 & 2 \\
\hline Jawa Barat & 78,36313 & 24,9206 & 53,62511 & 24,9206 & 2 \\
\hline Jawa Tengah & 89,53621 & 10,83436 & 65,95398 & 10,83436 & 2 \\
\hline Di Yogyakarta & 100,8915 & 7,921073 & 78,52987 & 7,921073 & 2 \\
\hline Jawa Timur & 82,33637 & 18,63446 & 58,0792 & 18,63446 & 2 \\
\hline Banten & 67,81212 & 49,10187 & 35,21937 & 35,21937 & 3 \\
\hline Bali & 96,02538 & 0 & 74,98529 & 0 & 2 \\
\hline NTB & 88,59683 & 12,1318 & 68,79151 & 12,1318 & 2 \\
\hline NTT & 86,07404 & 15,30406 & 61,69807 & 15,30406 & 2 \\
\hline Kalimantan Barat & 68,19714 & 47,00769 & 35,09256 & 35,09256 & 3 \\
\hline Kalimantan Tengah & 82,25741 & 30,07454 & 49,17509 & 30,07454 & 2 \\
\hline Kalimantan Selatan & 74,75191 & 36,92948 & 40,82986 & 36,92948 & 2 \\
\hline Kalimantan Timur & 88,27127 & 13,74933 & 66,74689 & 13,74933 & 2 \\
\hline Kalimantan Utara & 232,4592 & 274,4266 & 215,724 & 215,724 & 3 \\
\hline Sulawesi Utara & 91,12718 & 10,85926 & 68,18873 & 10,85926 & 2 \\
\hline Sulawesi Tengah & 71,91873 & 40,23259 & 37,64712 & 37,64712 & 3 \\
\hline Sulawesi Selatan & 72,01142 & 32,2397 & 47,64244 & 32,2397 & 2 \\
\hline Sulawesi Tenggara & 81,41584 & 22,8474 & 53,1835 & 22,8474 & 2 \\
\hline Gorontalo & 83,54772 & 17,22122 & 59,32806 & 17,22122 & 2 \\
\hline Sulawesi Barat & 78,64983 & 125,5459 & 102,1439 & 78,64983 & 1 \\
\hline Maluku & 70,19747 & 50,13856 & 33,31849 & 33,31849 & 3 \\
\hline Maluku Utara & 72,10136 & 38,3397 & 46,39503 & 38,3397 & 2 \\
\hline Papua Barat & 76,86977 & 121,2894 & 106,4806 & 76,86977 & 1 \\
\hline Papua & 74,0376 & 74,98529 & 0 & 0 & 3 \\
\hline Jumlah & 251,5723 & 1529,24 & 2069,877 & & \\
\hline Total Cost & & 850,689717 & & & \\
\hline
\end{tabular}

Setelah didapatkan hasil jarak dari setiap objek (cost) pada iterasi ke-1 maka lanjut ke iterasi ke-2. Inisialisasi kandidat medoid baru(non-medoid) pada iterasi ke-2 dapat dilihat pada tabel 3.4 berikut:

Tabel 4. Medoid Baru (Non-Medoid 1) Iterasi ke-2

\begin{tabular}{|l|l|l|r|r|r|r|r|}
\hline \multicolumn{1}{|c|}{ Inisial } & $\mathbf{2 0 0 4}$ & $\mathbf{2 0 0 5}$ & $\mathbf{2 0 0 6}$ & $\mathbf{2 0 0 7}$ & $\mathbf{2 0 0 8}$ & $\mathbf{2 0 0 9}$ & $\mathbf{2 0 1 0}$ \\
\hline Sulawesi Tengah(C1) & 72,95 & 68,63 & 73,74 & 70,63 & 72,04 & 72,77 & 74,78 \\
\hline Sulawesi Selatan(C2) & 71,97 & 66,55 & 75,79 & 72,65 & 73,89 & 75,99 & 76,65 \\
\hline Sulawesi Tenggara(C3) & 81,33 & 74,68 & 81,3 & 75,88 & 77,45 & 78,62 & 76,87 \\
\hline
\end{tabular}

K-Medoids Clustering Dalam Pengelompokkan Data Imunisasi Campak Balita (Siti Sundari) $\mid 692$ 
Tabel 5. Lanjutan Medoid Baru (Non-Medoid 1) Iterasi ke-2

\begin{tabular}{|c|c|c|c|c|c|c|c|}
\hline Inisial & $\mathbf{2 0 1 1}$ & $\mathbf{2 0 1 2}$ & $\mathbf{2 0 1 3}$ & $\mathbf{2 0 1 4}$ & $\mathbf{2 0 1 5}$ & $\mathbf{2 0 1 6}$ & $\mathbf{2 0 1 7}$ \\
\hline Sulawesi Tengah(C1) & 70,54 & 71,59 & 74,31 & 76 & 67,33 & 70,47 & 68,58 \\
\hline Sulawesi Selatan(C2) & 75,29 & 77,1 & 77,66 & 78,22 & 71,92 & 72,99 & 71,38 \\
\hline Sulawesi Tenggara(C3) & 74,79 & 75,81 & 78,4 & 79,39 & 71,59 & 74,56 & 71,87 \\
\hline
\end{tabular}

Hitung kembali jarak dari setiap objek pada iterasi ke-2 dengan menggunakan medoid baru pada tabel 3.4.

$$
D_{\text {aceh }, c 1}=\sqrt{\begin{array}{c}
\left((74,02-72,95)^{2}+(0-68,63)^{2}+(70,93-73,74)^{2}\right. \\
+(66,98-70,63)^{2}+(71,86-72,04)^{2}+(74,08-72,77)^{2} \\
+(74,24-74,78)^{2}+(74,13-70,54)^{2}+(75,1-71,59)^{2} \\
+(74,09-74,31)^{2}+(74,11-76)^{2}+(60,73-67,33)^{2} \\
\left.+(59,09-70,47)^{2}+(53,22-68,58)^{2}\right)
\end{array}}=71,91873
$$

Sehingga didapatkan hasil keseluruhannya dari iterasi ke-2 dapat dilihat pada tabel 3.6 sebagai berikut:

Tabel 6. Hasil Perhitungan Algoritma K-Medoids Iterasi ke-2

\begin{tabular}{|c|c|c|c|c|c|}
\hline \multirow{2}{*}{ Provinsi } & \multicolumn{3}{|c|}{ Jarak Ke Medoid } & \multirow{2}{*}{ Terdekat } & \multirow{2}{*}{$\begin{array}{c}\text { Cluster } \\
\text { Yang } \\
\text { Diikuti }\end{array}$} \\
\hline & C1 & $\mathrm{C} 2$ & C3 & & \\
\hline Aceh & 71,91873 & 72,01142 & 72,01142 & 71,91873 & 1 \\
\hline Sumatera Utara & 19,91459 & 25,46553 & 25,46553 & 19,91459 & 1 \\
\hline Sumatera Barat & 11,07023 & 19,58501 & 19,58501 & 11,07023 & 1 \\
\hline Riau & 9,929995 & 13,89013 & 13,89013 & 9,929995 & 1 \\
\hline Jambi & 12,76089 & 11,6799 & 11,6799 & 11,6799 & 1 \\
\hline Sumatera Selatan & 21,5769 & 14,03715 & 14,03715 & 14,03715 & 3 \\
\hline Bengkulu & 26,65353 & 19,69605 & 19,69605 & 19,69605 & 3 \\
\hline Lampung & 27,34701 & 19,27787 & 19,27787 & 19,27787 & 3 \\
\hline Kep. Bangka Belitung & 18,38122 & 10,28028 & 10,28028 & 10,28028 & 3 \\
\hline Kep. Riau & 78,451 & 74,71066 & 74,71066 & 74,71066 & 3 \\
\hline Dki Jakarta & 29,40755 & 23,11587 & 23,11587 & 23,11587 & 3 \\
\hline Jawa Barat & 19,32088 & 13,21098 & 13,21098 & 13,21098 & 3 \\
\hline Jawa Tengah & 31,61015 & 24,06678 & 24,06678 & 24,06678 & 3 \\
\hline Di Yogyakarta & 45,10679 & 37,73624 & 37,73624 & 37,73624 & 3 \\
\hline Jawa Timur & 23,01887 & 15,07444 & 15,07444 & 15,07444 & 3 \\
\hline Banten & 13,42127 & 18,43516 & 18,43516 & 13,42127 & 1 \\
\hline Bali & 40,23259 & 32,2397 & 32,2397 & 32,2397 & 3 \\
\hline NTB & 33,28346 & 24,00823 & 24,00823 & 24,00823 & 3 \\
\hline NTT & 26,89794 & 19,01886 & 19,01886 & 19,01886 & 3 \\
\hline Kalimantan Barat & 10,05772 & 16,53914 & 16,53914 & 10,05772 & 1 \\
\hline Kalimantan Tengah & 18,62203 & 16,41238 & 16,41238 & 16,41238 & 2 \\
\hline Kalimantan Selatan & 7,851115 & 10,04155 & 10,04155 & 7,851115 & 1 \\
\hline Kalimantan Timur & 31,88479 & 23,85058 & 23,85058 & 23,85058 & 2 \\
\hline Kalimantan Utara & 240,8193 & 248,0118 & 248,0118 & 240,8193 & 1 \\
\hline Sulawesi Utara & 33,87507 & 27,08849 & 27,08849 & 27,08849 & 3 \\
\hline Sulawesi Tengah & 0 & 11,6271 & 11,6271 & 0 & 1 \\
\hline Sulawesi Selatan & 11,6271 & 0 & 0 & 0 & 2 \\
\hline Sulawesi Tenggara & 19,21439 & 14,85877 & 14,85877 & 14,85877 & 2 \\
\hline Gorontalo & 24,91042 & 17,59364 & 17,59364 & 17,59364 & 3 \\
\hline
\end{tabular}




\begin{tabular}{|c|c|c|c|c|c|}
\hline \multirow[b]{2}{*}{ Provinsi } & \multicolumn{3}{|c|}{ Jarak Ke Medoid } & \multirow[b]{2}{*}{ Terdekat } & \multirow{2}{*}{$\begin{array}{c}\text { Cluster } \\
\text { Yang } \\
\text { Diikuti }\end{array}$} \\
\hline & C1 & $\mathrm{C} 2$ & C3 & & \\
\hline Sulawesi Barat & 101,4308 & 100,6836 & 100,6836 & 100,6836 & 2 \\
\hline Maluku & 13,82004 & 19,81427 & 19,81427 & 13,82004 & 1 \\
\hline Maluku Utara & 14,23434 & 11,8947 & 11,8947 & 11,8947 & 2 \\
\hline Papua Barat & 100,9995 & 98,82697 & 98,82697 & 98,82697 & 2 \\
\hline Papua & 37,64712 & 47,64244 & 47,64244 & 37,64712 & 1 \\
\hline Jumlah & 1227,297 & 1152,426 & 1152,426 & & \\
\hline Total Cost & \multicolumn{3}{|c|}{3532,148633} & & \\
\hline
\end{tabular}

c. Hitung Total Simpangan (S)

Setelah didapatkan nilai jarak antara iterasi ke-1 dan iterasi ke-2, hitung total simpangan (S) dengan mencari selisih dari nilai total cost baru- nilai total cost lama. Dengan ketentuan jika $\mathrm{S}<0$, maka tukar nilai objek dengan menentukan medoid baru.

$\mathrm{S}=$ Total cost baru - Total cost lama

$=3532,148633-3850,689717$

$=-318,541$

d. Ulangi langkah sebelumnya hingga $\mathrm{S}>0$, sehingga didapatkan cluster beserta anggota cluster masing-masing.

Setelah didapatkan nilai jarak iterasi ke-3, hitung total simpangan (S) dengan mencari selisih dari nilai total cost baru- nilai total cost lama. Dengan ketentuan jika $\mathrm{S}<0$, maka tukar nilai objek dengan menentukan medoid baru.

$\mathrm{S}=$ Total cost baru - Total cost lama

$=6857,06637-3532,148633$

$=3324,918$

Dengan nilai $\mathrm{S}>0$ proses cluster dihentikan, sehingga diperoleh anggota tiap cluster.

\subsection{Implementasi Sistem Rapidminer 5.3}

Pada tahap ini menampilkan hasil akhir serta langkah terakhir dalam penggunaan tools Rapidminer 5.3 ini. Hasil akhir yang akan ditampilkan adalah berupa pengelompokkan dimana hasil dari pengujian data akan tampak cluster dengan masing-masing anggota. Tampak pada gambar 3.1 berikut :

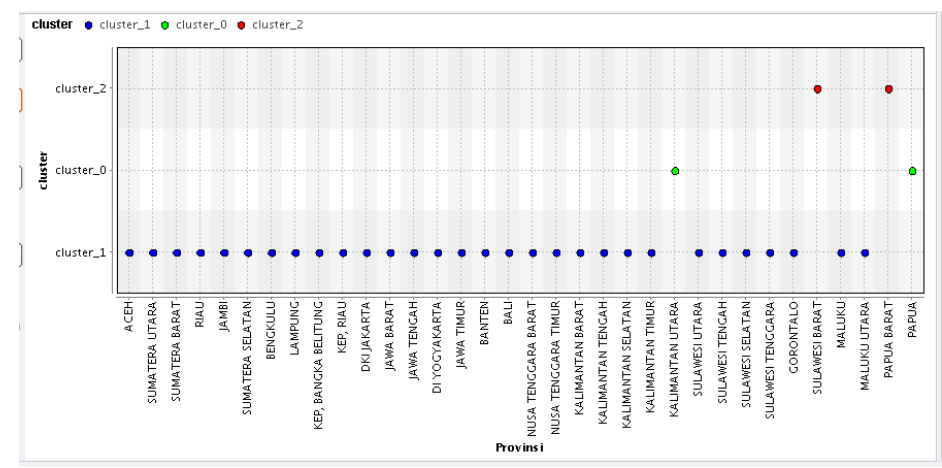

Gambar 2. Hasil Pengelompokkan 
Pada gambar 3.1 dapat dilihat bahwa terdapat 3 warna yang berbeda dimana cluster 1 berwarna biru, cluster 0 berwarna hijau, dan cluster 2 berwarna merah.

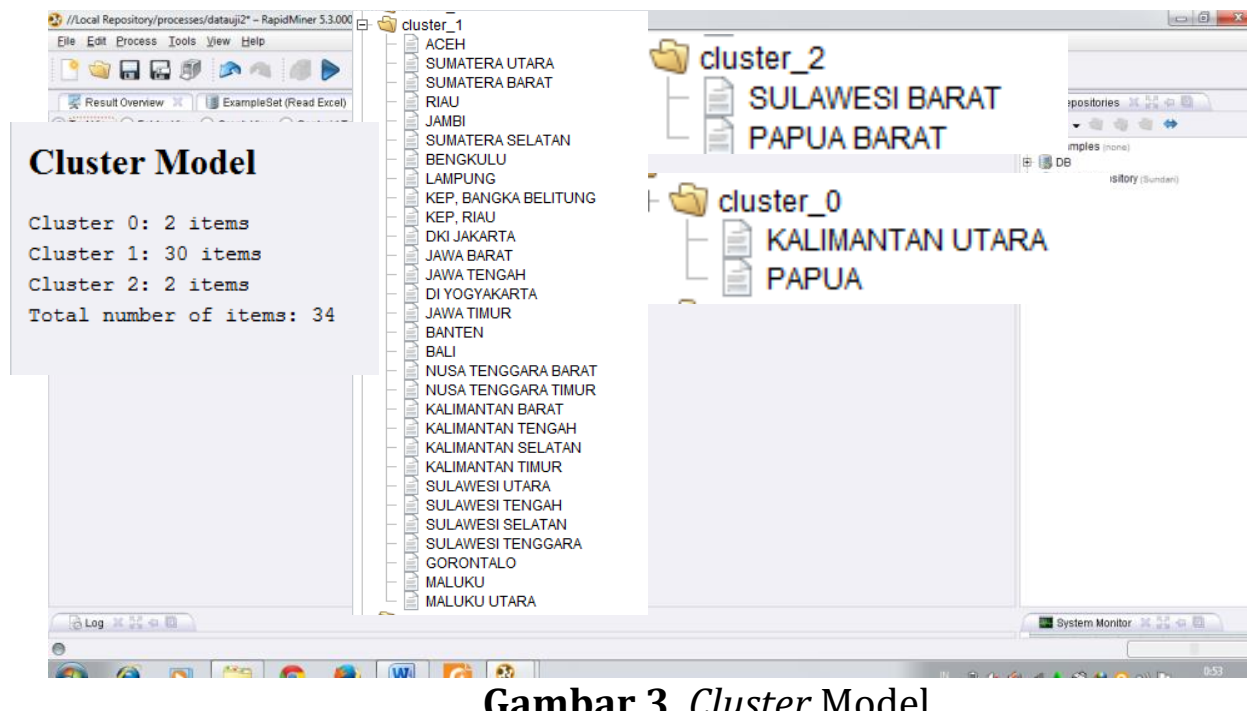

Dari gambar 3.2 dapat dilihat bahwa diperoleh 2 provinsi (kalimantan utara dan papua) pada cluster rendah, 30 provinsi (Aceh, Sumatera Utara, Sumatera Barat, Riau, Jambi, Sumatera Selatan, Bengkulu, Lampung, Kep.Bangka Belitung, Kep.Riau, Dki Jakarta, Jawa Barat, Jawa Tengah, Yogyakarta, Jawa Timur, Banten, Bali, NTB, NTT, Kalimantan Barat, Kalimantan Tengah, Kalimantan Selatan, Kalimantan Timur, Sulawesi Utara, Sulawesi Tengah, Sulawesi Selatan, Sulawesi Tenggara, Gorontalo, Maluku, Maluku Utara) pada cluster sedang dan 2 provinsi (sulawesi barat dan papua barat) pada cluster tinggi.

\subsection{Validasi Data}

Dalam melakukan validasi data perhitungan algoritma dengan sistem pada rapidminer menghasilkan hasil akhir berupa pengelompokkan dengan 3 cluster, serta data yang digunakan merupakan data yang valid dan sama dengan yang dipakai pada tools Rapidminer 5.3.

\section{KESIMPULAN}

Berdasarkan pembahasan pada bab sebelumnya dapat disimpulkan bahwa:

1. Penerapan data mining dengan metode $k$-medoids clustering dapat diterapkan. Sumber data yang digunakan pada penelitian ini adalah www.bps.go.id dengan subjek data imunisasi campak balita berdasarkan provinsi (2004-2017). Jumlah record yang digunakan sebanyak 34 provinsi dengan menghasilkan 3 cluster yakni cluster rendah sebanyak 2 provinsi cluster sedang sebanyak 30 provinsi dan cluster tinggi sebanyak 2 provinsi.

2. Berdasarkan hasil pengujian $k$-medoids untuk kasus persentase data imunisasi campak balita menggunakan tools Rapidminer 5.3 diperoleh hasil yang sama dengan analisis perhitungan metode dimana diperoleh 2 provinsi dengan cluster rendah yang menjadi pusat perhatian bagi pemerintah dalam melakukan 
sosialisasi dan pemerataan dalam pemberian imunisasi campak balita pada provinsi tersebut.

\section{DAFTAR PUSTAKA}

[1] WHO, “Organisasi Kesehatan Dunia,” www.depkes.go.id (25 Februari 2018), 2015.

[2] Kemenkes RI, Pusat Data dan Informasi Kementerian Kesehatan RI. 2016.

[3] M. G. Sadewo, A. P. Windarto, and S. R. Andani, "Pemanfaatan Algoritma Clustering Dalam Pengelompokkan Jumlah Desa/Kelurahan Yang Memiliki Sarana Kesehatan," KOMIK(Konferensi Nas. Teknol. Inf. dan Komputer), vol. I, no. 1, 2017.

[4] D. F. Pramesti, M. T. Furqon, and C. Dewi, "Implementasi Metode K-Medoids Clustering Untuk Pengelompokan Data Potensi Kebakaran Hutan / Lahan Berdasarkan Persebaran Titik Panas (Hotspot)," J. Pengemb. Teknol. Inf. dan Ilmu Komput., vol. 1, no. 9, 2017.

[5] S. Defiyanti, M. Jajuli, and N. rohmawati W, "Optimalisasi K - Medoid Dalam Pengklasteran Mahasiswa Pelamar Beasiswa dengan Cubic Clustering Criterion," TEKNOSI, vol. 3, no. 1, 2017.

[6] E. Setyowati, A. Rusgiyono, and M. A. Mukid, "Analisis Pengelompokan Daerah Menggunakan Metode Non- Hierarchical Partitioning K-Medoids dari Hasil Komoditas Pertanian Tanaman Pangan," J. GAUSSIAN, vol. 4, no. 4, 2015.

[7] D. Listiyanti, Y. A. Syahbana, and S. R. Henim, "Perancangan dan Implementasi Aplikasi Android Penentu Salient Area pada Video dengan Algoritma K-Medoids," in ANNUAL RESEARCH SEMINAR 2016, 2016, vol. 2, no. 1. 